\title{
Effects of Blended NPS Fertilizer Rates on Yield and Yield Components of Potato (Solanum tuberosum L.) Varieties at Dessie Zuria District, Ethiopia
}

\author{
Mekides Mekashaw ${ }^{1} \quad$ Melkamu Alemayehu $^{2} \quad$ Getachew Shumye $^{3 *} \quad$ Amare Hailesilasie $^{4}$ \\ 1.Mekdela Amba University, College of Agriculture, Department of Plant Science, P.O. Box 32, Tuluawlia, \\ Ethiopia \\ 2.Bahir Dar University, College of Agriculture and Environmental Sciences, Bahir Dar, Ethiopia \\ 3.Wollo University, College of Agriculture, Department of Plant Science, P.O. Box 1145, Dessie, Ethiopia \\ 4.International Livestock Research Institute, Addis Ababa, Ethiopia
}

\begin{abstract}
In Ethiopia, the average yield of potato is far below the potential due to different problems like in appropriate agronomic practices. Hence, this research was done to evaluate the effects of NPS fertilizer rates on yield and yield components of potato. The study was conducted at Dessie Zuria district, Ethiopia during dry season of 2015. A factorial combination of six level of NPS fertilizer $(0: 0: 0,111: 89.7: 0,111: 89.7: 16.52,55: 89.7: 16.52$, $111: 44.85: 8.26$ and $55: 44.85,8.26) \mathrm{kg} \mathrm{ha}^{-1}$ and two potato varieties were plotted in Randomized Complete Block Design with three replications. The highest plant height of potato $(87.60 \mathrm{~cm})$ was recorded on $111: 89.7: 16.52 \mathrm{~kg}$ $\mathrm{ha}^{-1}$ of NPS fertilizer rate. Belete variety supplied with 111: 89.7:16.52 $\mathrm{kg} \mathrm{ha}^{-1}$ of NPS fertilizer rate recorded the maximum days (124.3) to maturity of potato. Similarly, Belete variety recorded the higher biomass than local variety. The 111:89.7:16.52 kg ha-1 and 55.5:89.7:16.52 $\mathrm{kg} \mathrm{ha}^{-1}$ of NPS fertilizer rates showed the highest aboveground biomass $\left(103.24 \mathrm{~g} \mathrm{hill}^{-1}\right)$ and underground biomass of potato $\left(290.9 \mathrm{~g} \mathrm{hill}^{-1}\right)$ respectively. The highest average tuber number per hill (15.67), tuber weight per hill $(1.82 \mathrm{~kg})$, marketable $\left(53.61 \mathrm{t} \mathrm{ha}^{-1}\right)$, unmarketable $\left(0.542 \mathrm{tha}^{-1}\right)$ and total $\left(54.15 \mathrm{tha}^{-1}\right)$ tuber yield were recorded on potato which was applied with 55.5: 89.7:16.52 $\mathrm{kg} \mathrm{ha}^{-1}$ of NPS fertilizer rate. In all characteristics of growth and yield of potato, Belete variety was better than local variety. Similarly, potato fertilized with 55.5: 89.7:16.52 kg ha-1 of NPS fertilizer rate was showed highest yield than other rates.
\end{abstract}

Keywords: Potato; fertilizer rates; variety; marketable yield; tuber yield

DOI: $10.7176 / \mathrm{JBAH} / 10-13-01$

Publication date:July $31^{\text {st }} 2020$

\section{Introduction}

Potato (Solanum tuberosum L.) belongs to the family Solanaceae and genus Solanum (Thompson and Kelly, 1972). It is the major world food crops in its ability to produce high volume food per unit area and time (Israel et al., 2012). With the annual production of the world and Africa in the year of 2017 was about 388, 190, 674 and $25,011,823$ tons respectively (FAOSTAT, 2019).

In Ethiopia, potato is one among the most economically important crops as a source of food and cash in the country (Adane, 2010). Potato production in Ethiopia has increased from 349,000 tons in 1993 to around 932,701 tons in 2017 (FAOSTAT, 2019) and can potentially be grown on about $70 \%$ of arable land in the country (CSA, 2008/2009). However, the current area cropped with potato (about 160,000 ha) is small and the average yield (less than 10 tons $\mathrm{ha}^{-1}$ ) which is far below the potential of the crop (Adane, 2010). Inappropriate agronomic practices, shortage of seed tubers of improved potato varieties, soil nutrient depletion, moisture stresses, diseases and insect pests are the major constraints of potato production in the country (Tekalign and Hammes, 2005, Kefelegn et al. 2012)

The status of horticultural crops development including potato especially in the Northeast Ethiopia is negligible and mostly produced traditionally. However, with establishment and expansion of small scale irrigation schemes, the production of horticultural crops including potato is progressing, and yet the system of the production is constrained by various factors like lack of fertilizer (Alemu, 2014). Depletion of soil nutrient resulted from continuous cropping and/or low inherent soil fertility status; limited application of organic and inorganic nutrient sources fertilizers, leaching/erosion are some of the most important constraints limiting potato production in Eastern Africa including Ethiopia (Linus and Irungu, 2004). The national yield and variety trials data over several locations on different crop species clearly indicated that soil nutrient stress is the most significant factor controlling potato yield in Ethiopia.

Ethiopian farmers primarily rely on only two fertilizer types to supplement the nutrient requirement of the crops. Farmers are currently using $195 \mathrm{~kg} \mathrm{ha}^{-1}$ of di-ammonium phosphate (DAP) and $165 \mathrm{~kg} \mathrm{ha}^{-1}$ of urea to satisfy the phosphorous and nitrogen requirements of potato respectively throughout the country without considering the fertility status of the soil, the environment and the type of varieties used (Tewodros, 2014). But the Ethiopian soils 
lack most of the macro and micronutrients that are required to sustain optimal growth and development of crops (Shiferaw, 2014). Consequently, the yield and productivity of crops including potato in Ethiopia are much lower than other countries.

To alleviate the problem, the Ministry of Agriculture of Ethiopia has introduced a new blended fertilizer which contains nitrogen, phosphorous and sulfur (NPS) with the ratio of $19 \% \mathrm{~N}, 38 \% \mathrm{P}_{2} \mathrm{O}_{5}$ and $7 \% \mathrm{~S}$. This fertilizer has been currently distributed in Ethiopian crop production system (Ministry of Agriculture and Natural Resource (MoANR, 2013). However the situation is challenging for the researchers and smallholder farmers to understand the effects and the optimum rates of the newly introduced blended NPS fertilizer that contains sulfur for production of crops including potato. Therefore, the objective of this study is to evaluate the effects of different rates of NPS fertilizer on yield and yield components of potato in Abaso Kotu, Dessie Zuria district, Northeast Ethiopia.

\section{Materials and methods}

\subsection{Description of the Study Area}

The experiment was conducted on farmers' training center of Abaso Kotu peasant association, Dessie Zuria district, northeast, Ethiopia. The experimental site is located at $039^{0} 30^{\prime} 22.7^{\prime \prime} \mathrm{E}$, and $11^{\circ} 05^{\prime} 30.8^{\prime \prime} \mathrm{N}$ at an elevation of 2270 m.a.s.l. The average annual minimum and maximum temperatures of the district is about $10^{\circ} \mathrm{C}$ and $25^{\circ} \mathrm{C}$, respectively. The annual average rainfall of the district ranges $900-1100 \mathrm{~mm}$ with bimodal distribution and the soil of the site is sandy loam.

\subsection{Experimental materials, treatments and design}

The experiment was consisted of six NPS(0:0:0, 111:89.7:0, 111:89.7:16.52, 55.5: 89.7:16.52, 111:44.85:8.26, 55.5:44.85:8.26) fertilizer rates taken on the basis of the $\mathrm{N}$ and $\mathrm{P}_{2} \mathrm{O}_{5}$ fertilizer application rate of recommended $195 \mathrm{~kg} \mathrm{ha}^{-1}$ Diammonium Phosphate (DAP) and $165 \mathrm{~kg} \mathrm{ha}^{-1}$ urea for major potato producing area of Ethiopia (Agajie et al., 2007). Two potato varieties (Local and Belete) used as planting material. The experimental plots were laid out as a randomized complete block design (RCBD) in factorial arrangements with three replications. Each plot was 3 meter wide and 3 meter long with $1 \mathrm{~m}$ and 1.5 mspacing between plots and blocks respectively. Each plot contained 4 rows with 10 plants per row. Medium sized, healthy and well-sprouted potato tubers were planted at the spacing of $30 \times 75 \mathrm{~cm}$.

\subsection{Management of the experimental plots}

The experimental site was prepared using draft animals and human labor. Soil sample was taken randomly from five spots of the experimental area diagonally at the depth of $30 \mathrm{~cm}$ before planting and mixed to make a composite. The collected samples were air-dried and grounded to pass through $2 \mathrm{~mm}$ sieve for analysis of physical and chemical properties. The $\mathrm{pH}$ of the soil was determined by diluting the soil with water in 1:2.5 ratios by using $\mathrm{pH}$ meter whereas electrical conductivity was measured by a conductivity meter (Van Reeuwijk, 1992). The organic carbon was determined by oxidizing the carbon under standard conditions with potassium dichromate in sulfuric acid solution (Walkley and Black, 1934). Finally, the organic matter content of the soil was calculated by multiplying the organic carbon percentage by 1.724 . The total nitrogen content in soils was determined using the Kjeldahl procedure (Horneck et al., 2011). Available phosphorous and Exchangeable bases (K and Na) were determined by Olsen (1954) and Rowell (1994) methods respectively. Salinity of the sample soils was measured as electrical conductivity (EC) and expressed in decisiemens (ds/m) (Rhoades et al., 2002). Particle size (soil texture) was determined by using hydrometer method of Bouyoucos (Day, 1965). First irrigation was given just after planting and subsequent irrigations were given when required. Weeding was done manually whenever needed. Earthing-up was done twice which promotes stolon production that develops in to tubers. There was no major diseases and pests' incidence encountered.

\subsection{Method of data collection and analysis}

Both the growth and yield parameters were collected from $6.075 \mathrm{~m}^{2}$ of the net plot area. The collected parameters were plant height $(\mathrm{cm})$, number of stems per hill, days to $50 \%$ flowering, days to physiological maturity, Above ground biomass $\left(\mathrm{g} \mathrm{hill}^{-1}\right)$, below ground biomass $\left(\mathrm{g} \mathrm{hill}^{-1}\right)$, total biomass ( $\mathrm{g}$ hill $\left.{ }^{-1}\right)$, tuber numbers per hill, average tuber weight $\left(\mathrm{kg} \mathrm{hill}^{-1}\right)$, unmarketable tuber yield $\left(\mathrm{t} \mathrm{ha}^{-1}\right)$, marketable tuber yield $\left(\mathrm{t} \mathrm{ha}^{-1}\right)$ and tuber yield $\left(\mathrm{t}\right.$ ha $\left.{ }^{-1}\right)$. The collected data were subjected to the analysis of variance (ANOVA) by using SAS (Statistical Analysis System) version 9.0.1. The least significant difference (LSD) test at $5 \%$ probability was used for mean separation of the treatments.

\section{Results}

\subsection{Soil Properties before Planting}

The physical and chemical properties of the soil of the experimental field are indicated in Table 1. The soil textural class of the experimental site is Sandy loam. The soil of experimental field is slightly acidic in $\mathrm{pH}(6.8)$, slightly 
saline in electrical conductivity $(4.45 \mathrm{ds} / \mathrm{m})$, very low in organic sulfur $(0.0114 \%)$, high organic carbon $(1.326 \%)$, very high organic matter $(2.286 \%)$, low in total N $(0.1143 \%)$, Extremely low in available phosphorus $(11.18 \mathrm{ppm})$ and high in Exchangeable K $(1.242 \mathrm{meq} / 100 \mathrm{~g})$ ions. From the results of soil analysis it can be depicted all sulfur, nitrogen and phosphorus may be yield limiting for potato production in the area.

Table 1:-

\subsection{Phonological and Growth components of potato Plant height and Stem number per hill}

Varieties had no significant effect on plant height but fertilizer rates showed significant effect at $(\mathrm{p} \leq 0.05)$. Accordingly, the highest plant height of potato $(87.60 \mathrm{~cm})$ was recorded on fertilizer rate of $111: 89.7: 16.52 \mathrm{~kg} \mathrm{ha}^{-}$ ${ }^{1}$ of NPS while the shortest plant height $(62.27 \mathrm{~cm})$ was recorded on plants where no fertilizer was applied. On the other hand, both the interaction and the main effect of variety and fertilizer rate showed statistically non-significant variation on stem number per hill $(\mathrm{p} \leq 0.05)$ (Table 2). Despite the fact that stem density is one of the most important yield components in potato, the results of the present study showed that the influences of variety and fertilizer rates on stem number were non-significant.

\section{Days to flowering}

Varieties had significant effect ( $\mathrm{p} \leq 0.05$ ) on days to $50 \%$ flowering but not fertilizer rates. The longer (59.17) days to $50 \%$ flowering of potato was recorded on Belete than local variety. This may be due to differences in genetic makeup of the two varieties (Table 2).

Table 2:-

\section{Days to maturity}

The analysis of variance revealed that there was significant interaction effect between variety and NPS fertilizer rate on days to physiological maturity of potato. The maximum days (124.3) to physiological maturity of potato was recorded on Belete variety supplied with 111: 89.7:16.52 $\mathrm{kg} \mathrm{ha}^{-1}$ of NPS fertilizer rate. But the shortest days to physiological maturity (111) was recorded on Belete variety in the absence of fertilizer application but not significant difference with Belete variety treated with 111:89.7:0 fertilizer rate and local variety treated with 55.5: 44.85:8.26, 111:44.85:8.26 fertilizer rates and untreated with fertilizer (Table 3).

Table 3:-

\subsection{Yield and Yield Components of Potato}

\section{Above ground, below ground and total biomass}

The higher aboveground biomass $\left(91.8 \mathrm{~g} \mathrm{hill}^{-1}\right)$, underground biomass $\left(261.2 \mathrm{~g} \mathrm{hill}^{-1}\right)$ and total biomass $(352.9 \mathrm{~g}$ hill $\left.^{-1}\right)$ were recorded on Belete variety. In the case of fertilizer rates, the highest above ground biomass $(103.24 \mathrm{~g}$ hill $^{-1}$ ) was recorded on potato plants which were fertilized with 111:89.7:16.52 kg ha-1 of NPS fertilizer rate. While the highest underground biomass of potato $\left(290.9 \mathrm{~g} \mathrm{hill}^{-1}\right)$ was recorded on potato fertilized with 55.5:89.7:16.52 $\mathrm{kg}$ ha $^{-1}$ NPS fertilizer treatment, but not significant difference with potato fertilized with 111:89.7:0, 111:89.7:16.52 and 55.5:44.85:8.26 $\mathrm{kg} \mathrm{ha}^{-1}$ of NPS fertilizer rates. Similarly, the highest total biomass (378.8 $\mathrm{g}$ hill $^{-1}$ ) was recorded on potato plants which were fertilized with 55.5: 89.7:16.52 kg ha-1 of NPS but not significant difference with potato fertilized with 111:89.7:16.52 kg ha-1 of NPS fertilizer rate. The lowest aboveground biomass $\left(45.60 \mathrm{~g} \mathrm{hill}^{-1}\right)$, underground biomass $\left(171.1 \mathrm{~g} \mathrm{hill}{ }^{-1}\right)$ and total biomass $\left(216.7 \mathrm{~g} \mathrm{hill}^{-1}\right)$ were recorded potato plants with nil fertilizer application.

Table 4:-

\section{Average tuber number per hill}

The analysis of variance revealed that there was no significant difference between varieties in their average tuber number per hill. However, the fertilizer rates affected the tuber number significantly. The highest average tuber number per hill (15.67) was recorded on potato which was applied with 55.5: 89.7:16.52 $\mathrm{kg} \mathrm{ha}^{-1}$ of NPS but not significant different with all NPS fertilizer rates applied to potato plants while the untreated with NPS fertilizer potato plants recorded the lowest tuber number per hill (Table 4).

\section{Average tuber weight per hill}

The analysis of variance revealed that both variety and NPS fertilizer rates affected the tuber weight per hill of potato. The higher tuber weight per hill $(1.606 \mathrm{~kg})$ was recorded on Belete variety than local variety. On the other hand, potato which was supplied with 55.5: 89.7:16.52 $\mathrm{kg} \mathrm{ha}^{-1} \mathrm{NPS}$ fertilizer rate scored the highest (1.82 kg hill$\left.{ }^{1}\right)$ tuber weight per hill but not significant difference with 55.5:89.7:16.52, 111:44.85:8.26 and 55.5:44.85:8.26 kg $\mathrm{ha}^{-1}$ of NPS fertilizer rates. The lowest tuber weight per hill $\left(1.123 \mathrm{~kg} \mathrm{hill}^{-1}\right)$ was recorded on unfertilized potato but not significant difference with potato fertilized with 111:89.7:0 $\mathrm{kg} \mathrm{ha}^{-1}$ NPS rate (Table 5).

Table 5:-

\section{Tuber Yield of Potato}

The variety and NPS fertilizer rates showed significant difference $(\mathrm{p} \leq 0.05)$ on marketable, unmarketable and total tuber yield of potato. All the higher marketable $\left(48.11 \mathrm{t} \mathrm{ha}^{-1}\right)$, unmarketable $\left(0.501 \mathrm{t} \mathrm{ha}^{-1}\right)$ and total $\left(48.6 \mathrm{t} \mathrm{ha} \mathrm{a}^{-1}\right)$ 
tuber yield of potato were obtained from Belete variety compared to the local variety. Similarly, the highest marketable $\left(53.61 \mathrm{t} \mathrm{ha}^{-1}\right)$, unmarketable $\left(0.542 \mathrm{t} \mathrm{ha}^{-1}\right)$ and total $\left(54.15 \mathrm{t} \mathrm{ha}^{-1}\right)$ tuber yield were obtained from potato which were supplied with 55.5: 89.7:16.52 $\mathrm{kg} \mathrm{ha}^{-1}$ of NPS fertilizer rate but not significant difference with potato supplied with 111: 89.7:0, 111: 89.7:16.52 and 55.5: 44.85:8.26 $\mathrm{kg} \mathrm{ha}^{-1}$ of NPS fertilizer rates. While the lowest marketable $\left(31.5 \mathrm{t} \mathrm{ha}^{-1}\right)$, unmarketable $\left(0.358 \mathrm{t} \mathrm{ha}^{-1}\right)$ and total $\left(31.85 \mathrm{t} \mathrm{ha}^{-1}\right)$ tuber yields of potato were obtained from potato which were not supplied by NPS fertilizer (Table 5 ).

\section{Discussion}

\section{Plant height and Stem number per hill}

The potato plant height was significantly affected by NPS fertilizer rates which correlate with the finding of Alemayehu and Jemberie, 2018. The increased potato plant height by application of NPS may be attributed by physiological stem elongation effect of nitrogen which is also observed by other authors (Lamessa and Zewdu, 2016; Sriom, 2017). Similarly, Yohannes (1994) who reported significant increment in plant height of enset crops as the rates of $\mathrm{N}$ and $\mathrm{P}$ applications were increased. The effects of nitrogen on plant height seemed to be enhanced due to the presence of PS. This may be due to the fact that these three important plant nutrients have interrelated metabolic and physiological functions in the plants. Thus, it is possible to conclude from the present observation that $\mathrm{P}$ and $\mathrm{S}$ are helpful in amplifying the effects of $\mathrm{N}$ on plant height. Also, the increase in growth parameters under sulphur application might be due to improved sulphur availability, which in turn enhanced the plant metabolism and photosynthetic activity resulting into better growth. These findings are in agreement with Singh and Shrivastava, 1995 and Jat et al. 2013). The increased plant heights have been also reported on wheat and garlic by application of NPS fertilizer (Abera et al, 2018 and Yayeh et al, 2017).

Despite the fact that stem density is one of the most important yield components in potato, the results of the present study showed that the influences of variety and fertilizer rates on stem number were not significant difference. This could be due to the fact that stem number is determined very early in the ontogeny of yield (Lynch and Tai, 1989). It could also be due to the case that this trait was not influenced much by the mineral nutrition, as the stem number is the reflection of storage condition (Allen, 1978), physiological age of the seed tuber (Lynch and Tai, 1989; De La Morena et al., 1994) and tuber size (Harris, 1978).

\section{Days to flowering and maturity}

The effects of NPS fertilizer rates was not significant difference on days to $50 \%$ flowering which is not in line with the findings of Alemayehu and Jemberie (2018), Lauer (1986) and Ojala et al. (1990) who observed an excessive vegetative growth and thus delayed flowering of potato with high level of nitrogen fertilizer. Nitrogen fertilizer increased the leaf area which increases the amount of solar radiation intercepted and consequently, increases days to flowering, days to physiological maturity, plant height and dry matter production of different plant parts (Krshnappa, 1989). In contrast to nitrogen effect, increasing phosphorous application shortened the time required to attain flowering stage of potato plants because phosphorus possesses a very useful effect on cell division and albumen formation, flowering and fruiting including seed formation and crop maturation $(\mathrm{FAO}, 1984)$ and stunting of growth (Brady and Weil, 2002). Also, sulfur has role in better partitioning of the photosynthates in the shoot and tubers (Sud and Sharma, 2002). Hence, the reason for non-significance difference on days to flowering between fertilizer rates in this study might be due to the counteract of phosphorus and sulfur on the effect of nitrogen. But in days to physiological maturity the interaction effect between variety and NPS fertilizer rate was significantly different. The maximum days to physiological maturity was recorded on Belete variety supplied with the maximum NPS fertilizer rate while the shortest days to maturity was recorded on the unfertilized potato plant of same variety. This finding is supported with the results of Abera et al, (2018), Alemayehu and Jemberie, (2018), Wilcox and Hoff, (1970), Kleinkopf et al, (1987) and FAO, (1984).

\section{Above ground, below ground and total biomass}

The above ground biomass, below ground biomass and total biomass of the potato were significantly affected by the main effects of NPS rate and variety. The result of this study revealed that, the above ground biomass, below ground biomass and total biomass were higher in potato plants which were supplied with NPS fertilizer rates than unfertilized potato plants. Also, the biomass yield was increased as the rates of NPS fertilizer increases. Biomass yield increment in response to $\mathrm{N}, \mathrm{P}$ and $\mathrm{S}$ fertilization indicates that all nutrients could exert a significant influence on biomass production and partitioning to the different parts of potato plant.

The increment of dry matter yield per plant was also more apparent in plants from the applied fertilizer which is probably due to less competition among the plants for nutrients. The findings of Millard and Marshall (1986) who reported a significant increment in canopy dry matter yield of potato as $\mathrm{N}$ application increased supports the results obtained in this study. The results of the present study clearly indicated that the application of NPS fertilizer increased biomass of potato varieties which are in line with the findings of various researchers (Sharma \& Arora, 1987; Yohannes, 1994). 
difference had significant influence on number of tuber per potato plant (Sharma et al, 2015). The average tuber numbers per hill recorded from potato applied with NPS fertilizer rates were higher than unfertilized potato. Increasing stem density over a wide range either by planting larger seed tubers or more seed tubers for most varieties resulted in increased number of tubers per unit area (Allen, 1972; Gray and Hughes, 1978). Contradicting results have also been reported by different investigators regarding the effect of mineral nutrition on the number of tubers set per plant. As reported, the application of N, P and S significantly increased the number of tubers set per unit area (Lynch and Rowberry, 1997; Sommerfeldt and Knustan, 1965; Hanley et al., 1965, Sharma et al, 2015, Sharma and Arora, 1987; White and Sanderson, 1983) which correlate with the finding of this study.

\section{Average tuber weight per hill}

Average tuber weight per hill has been reported to be the third most important yield component of potato after stem and tuber number contributing to the total tuber yield (Lynch and Tai, 1989; De La Morena et al., 1994). In agreement with the result of the present study, Sharma et al., 2015, Berga et al. (1994) and Bereke (1994) reported that there were significant differences between varieties for average tuber weight of potato. Saluzzo et al. (1999) suggested that variety with higher average tuber weight in addition to its late maturity might also be more efficient in dry matter partitioning to tubers than variety with lower average tuber weight. In this study, the higher average tuber weight per hill was recorded in almost all NPS fertilizer supplied potato than unfertilized potato. The increased average weight of tubers with the supply of nitrogen fertilizer could be due to luxuriant growth, more foliage and leaf area and higher supply of photosynthate which helped in producing bigger tubers resulting in higher yield (Sharma and Arrora, 1987). Also, this positive effect of $\mathrm{N}$ on tuber weight increase could be attributed to more interception of photosynthetically active radiation, more dry matter accumulation and partitioning to tubers (Saluzzo et al., 1999). It also, influenced by P fertilizers through its effect on the number and size of tubers produced and the time at which maximum yield is obtained (Sommerfeld and Knutson, 1965; Sharma and Arora, 1987). Also, Sulfur levels showed significant influence on average tuber weight per potato plant (Sharma et al., 2011 and Sharma et al., 2015).

\section{Tuber yield}

The marketable, unmarketable and total tuber yield from Belete variety was higher than Local variety. This could be the variation in genetical characteristics. Similarly, Alemayehu and Jemberie, (2018), Sharma et al., (2015) and Sharma et al., (2011) also reported significant variation in tuber yield of different potato varieties. On the other hand, the marketable, unmarketable and total tuber yields were obtained from potato which was supplied with NPS fertilizer rates. The lowest marketable, unmarketable and total tuber yield was obtained from potato which was not supplied with NPS fertilizer. In line with this finding, increasing NPS application rates in generally increased marketable, unmarketable and total tuber yields of the tested potato varieties (Alemayehu and Jemberie, 2018). The yield increment in marketable tuber yield due to increased phosphorus application in the presence of recommended nitrogen and sulfur implying that those mineral nutrient can contribute to produce more and healthy marketable size tubers due to their combination effect in delaying tuber growth associated with greater partitioning of dry matter to the above ground portion that ultimately contributed to the increased marketable and total tuber yield. Although $\mathrm{P}$ had shown a positive effect on tuber yield, the percentage of yield increment due to $\mathrm{P}$ was smaller than the yield increment due to $\mathrm{N}$. This could probably be explained, at least in part, by a smaller increase in leaf area index due to P compared with the response to N. Moreover, P was reported to lead to earlier closure of canopy and shorten the growing period (Sommerfeldt and Knutson, 1965). Similarly, Sulphur levels showed significant influence on grade wise tuber yield (Sharma et al., 2011 and Sharma et al., 2015) This might be the increase in tuber yield with increasing sulphur levels may be due to its role in better partitioning of the photosynthates in the shoot and tubers (Sud and Sharma, 2002). Generally, the present study results revealed that application of NPS fertilizer increased tuber yields of potato varieties which agrees with the reports of Alemayehu and Jemberie, (2018), Yayeh et al., (2017), Boke, (2014) and Ayichew et al., (2009).

\section{Conclusion}

In the present study, most growth and yield components of potato varieties were increased with increased application rates of NPS fertilizer and their responses were different. Accordingly, the highest plant height of potato $(87.60 \mathrm{~cm})$ was recorded on fertilizer rate of $111: 89.7: 16.52 \mathrm{~kg} \mathrm{ha}^{-1}$ of NPS fertilizer. The maximum days (124.3) to maturity of potato was recorded on Belete variety supplied with 111:89.7:16.52 $\mathrm{kg} \mathrm{ha}^{-1}$ of NPS fertilizer while the shortest days (111) was recorded on Belete variety in the nil fertilizer application. The higher aboveground biomass $\left(91.8 \mathrm{~g} \mathrm{hill}^{-1}\right)$, underground biomass $\left(261.2 \mathrm{~g} \mathrm{hill}^{-1}\right)$ and total biomass $\left(352.9 \mathrm{~g} \mathrm{hill} \mathrm{l}^{-1}\right)$ were $^{-}$ recorded on Belete variety. In the case of fertilizer rates, while the highest underground biomass $\left(290.9 \mathrm{~g} \mathrm{hill}^{-1}\right)$ and total biomass $\left(378.8 \mathrm{~g} \mathrm{hill}^{-1}\right)$ of potato was recorded on potato fertilized with 55.5:89.7:16.52 $\mathrm{kg} \mathrm{ha}^{-1} \mathrm{NPS}$ fertilizer treatment. The highest average tuber number per hill (15.67), tuber weight $\left(1.82 \mathrm{~kg} \mathrm{hill}^{-1}\right)$, marketable (53.61 $\left.\mathrm{t} \mathrm{ha}^{-1}\right)$, unmarketable $\left(0.542 \mathrm{t} \mathrm{ha}^{-1}\right)$ and total $\left(54.15 \mathrm{tha}^{-1}\right)$ tuber yield was recorded on potato which was applied with 55.5: 89.7:16.52 $\mathrm{kg} \mathrm{ha}^{-1}$ of NPS fertilizer rate. Also, all the higher marketable $\left(48.11 \mathrm{t} \mathrm{ha} \mathrm{h}^{-1}\right)$, unmarketable $\left(0.501 \mathrm{t} \mathrm{ha}^{-1}\right)$ and total $\left(48.6 \mathrm{t} \mathrm{ha}^{-1}\right)$ tuber yield of potato were obtained from Belete variety compared 
to the local variety. Therefore, producing potato with different NPS fertilizer rates in different potato variety had

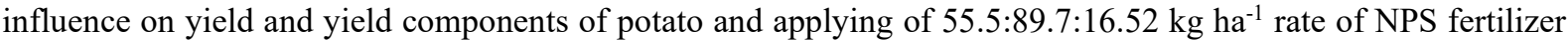
increased almost all yield and yield components of potato varieties.

\section{Acknowledgements}

We would like to acknowledge ILRI-LIVES project funded by Global Affairs of Canada for the financial support to conduct this study.

\section{Reference}

Abera T., Belete K. and Tana T., 2018. Effect of Blended NPS Fertilizer Supplemented with Nitrogen on Yield Components and Yield of Bread Wheat (Triticumaestivum L.). Journal of Natural Sciences Research.8:11, pp: 90-96.

Adane, H., P.M. Miranda, A.T. Meuwissen, J.M. Willemien, A.O.L. Lommen, T. Admasu, and C.S. Paul. 2010. Analysis of Seed Potato Systems in Ethiopia. American Journal of Potato Research. 87:537-552.

Agajie, T., K. Wachira, M. Gebre, G. Wolde, L. Berga and N. Demeke, 2007. Adoption and impact of potato production technologies in selected districts of Oromiya and Amhara Regions of Ethiopia. Ethiopian Institute of Agricultural Research, Research Report.

Alemayehu M. and Jemberie M. 2018. Optimum rates of NPS fertilizer application for economically profitable production of potato varieties at Koga Irrigation Scheme, Northwestern Ethiopia. Cogent Food and Agriculture. 4:1439663.

Alemu K.T.,2014. Potato value chain in Ethiopia: Cases of Sinan and Bibugn Districts in East Gojjam. Time Journals of Agriculture and Veterinary Sciences, 2:6

Allen, E.J., 1972. The effect of row width on the yield of three potato varieties. Journal of Agricultural Sciences of Cambridge, $7 \mathrm{p}: 315-321$.

Ayichew, Z., Tsegaw, T., and Dessacha, N. 2009. Response of potato (Solanum tuberosumL.) to different rates of nitrogen and phosphorus fertilization on vertisols at Debre Berhan, in the central highlands of Ethiopia. African Journal of Plant Science, 3:2, pp: 16-24.

Berga Lemaga, G. Hailemariam and G. Woldegiorgis, 1994. Prospects of seed potato production in Ethiopia. pp. 254-275. In: E. Hareth, D. Lemma (ed.). Proceedings of the Second National Horticultural Workshop of Ethiopia. EARO-FAO, Addis Ababa, Ethiopia.

Boke, S. 2014. Effects of organic and inorganic fertilizer application on potato yield and soil properties on Alisols of Chencha. Africa Journal of Science, 2:8, pp:123-132.

Brady, N. C., and R. R. Weil. 2002. The Nature and Properties of Soils, $13^{\text {th }}$ ed., Pearson Educ. Group, Upper Saddle River, New Jersey.

CSA (Central Statistical Agency of Ethiopia). 2008/2009. Agricultural sample survey: Report on area and production of crops, Addis Abeba, Ethiopia. P:126.

Day, P. R. 1965. Hydrometer method of particle size analysis. In C. A. Black (Ed.). Methods of soil analysis: American society of agronomy no. 9. Part 2: pp. 562-563. Milwaukee: Wisconsin Argon.

De La Morena, I.A., L.F. Guillen and G. De La Morel, 1994. Yield development in potatoes as influenced by cultivar and the timing and level of $\mathrm{N}$ fertilizer. American Potato Journal, 71:165-173.

E.J., 1978. Plant density. pp. 279-324. In: P.M. Harris (ed.). The Potato Crop: The Scientific Basis for Improvement. Chapman and Hall, London.

FAO (Food and Agriculture Organization), 1984. World review: the ten years since the World Food Conference Urbanization, agriculture and food systems, Agriculture Series, No. 18.Rome.

FAOSTAT. 2019. Statistical database. Rome: Food and Agricultural Organization of United Nations.

Gray, D. and Hughes, J.C. 1978. Tuber quality. In: The Potato Crop- the Scientific Basis for Improvement, (ed. P.J. Harris), pp. 504-544. Chapman and Hall, London.

Hanley F., Jarvis R.H., and Ridgman W.J. 1965. The effects of fertilizers on the bulking of Majestic Potatoes. Journal of Agricultural Sciences. 65:159-169.

Harris, P.M., 1978. Mineral Nutrition. pp. 195-243. In: P.M. Harris, (ed.).The potato Crop: The Scientific Basis for Improvement. Chapman and Hall. London.

Horneck, D. A., Sullivan, D. M., Owen, J. S., \& Hart, J. M. 2011.Soil test interpretation guide (p. 1478). EC: Oregon State University.

Israel Z., Ali M., and Solomon T. 2012. Effect of Different Rates of Nitrogen and Phosphorus on Yield and Yield Components of Potato (Solanum tuberosum L.) at Masha District, Southwestern Ethiopia. International Journal of Soil Science, 7: 146-156.

Jat, S.R., Patel, B.J., Shivran, A.C., Kuri, B.R. and Jat G. 2013. Effect of phosphorus and sulphur levels on growth and yield of under rainfed conditions. Annals of Plant and Soil Research. 15:2, pp:114-117.

Kefelegn, H., A. Chala, B. Kassa, and P. K. Tiwari. 2012. Evaluation of different potato variety and fungicide 
combinations for the management of potato late blight (Phytophthora infestans) in Southern Ethiopia. International Journal of Life Sciences 1:1, P:8-15.

Kleinkopf, G.E., D.T. Westermann, M.J. Wille, and G.D. Kleinscmidt. 1987. Specific Gravity of Russet Burbank Potatoes. American Potato Journal 64: 579-587.

Krishnippa, K. S. 1989. Effect of fertiliser applications on dry matter and N, P, and K accumulation in the potato at different stages of growth. Mysore Journal of Agriculture Science 23:349-354.

Lamessa K., Zewdu A. 2016. Effect of spacing and fertilizer dose on growth and yield of potato (Solanumtuberosum L.) Gudane variety at West Hararghe, Eastern Ethiopia. International Journal of Horticulture and Ornamental Plants 2(1): 011-018.

Lauer, D.A., 1986. Response of Nooksack potatoes to nitrogen fertilizer. American Potato Journal. 63:251-262.

Linus, M.M.M. and Irungu, 2004. Effect of integrated use of inorganic fertilizer and organic manures on bacterial wilt incidence (BWI) and tuber yield in potato production systems on hill slopes of central Kenya. Journal of Mountain Science, 1:1, pp 81-88.

Lynch D.R. and Rowberry R.G. 1997. Population density studies with Russet Burbank potatoes. II. The effect of fertilization and plant density on growth, development, and yield. American Potato Journal, 54: 57-71.

Lynch, D.R. and G.C. Tai, 1989. Yield and yield component response of eight potatoes genotypes to water stress. Crop Science, 29: 1207-1211.

Millard, P. and Marshall, B., 1986. Growth, N uptake and partitioning within the potato (Solanum tuberosum L.) crop, in relation to N application. Journal of Agricultural Science of Cambridge, 107: 421-429.

Minstry of Agriculture and Natural Resource (MoANR). 2013. Ethiopia is transitioning into the implementation of soil test based fertilizer use system.www.moa.gov.et/documents/93087/

Ojala, C., J., Stark J. C., and Kleinkop G.E.1990. Influence of irrigation and nitrogen management on potato yield and quality. American Potato Journal 67,29-43.

Olsen, S.R., Watenabe, V.C., Dean, L.A., 1954. Estimate of available phosphorous in soil by extraction with sodium bicarbonate. USDA Circular. No. 939. USA.

Rhoades, J. D., Chanduvi, F., \& Lesch, S. M. 2002. Soil salinity assessment: Methods and interpretation of electrical conductivity measurement. Rome: Food and Agriculture of the United Nations (FAO).

Rowell, D. 1994. Soil science: Methods and applications. Longman Limited. England. 350p.

Saluzzo J.A., H.E. Echeverria, F.H. Andrade and M. Huarte. 1999. Nitrogen nutrition of potato cultivars differing in maturity. Journal of Agronomy of Crop Science. 183:157-165.

SAS (Statistical Analysis Software). SAS/STAT version 9.2 user's guide. Cary: SAS Institute Inc.; 2008.

Sharma, C. U. and B. R. Arora.1987. Effect of nitrogen, phosphorus and potassium application on yield of potato tubers (Solanum tuberosum L.).The Journal of Agricultural Science, 108:2, pp: 321-329.

Sharma, D.K., Kushwah, S.S. and Verma, K.S., 2015. Effect of Sulphur on growth, yield and economics of potato cultivars. Annals of Plant and Soil Research. 17:1, pp: 45-49.

Sharma,D.K., Kushwah, S.S. and Nema P.K. and Rathore, S.S. 2011. Effect of Sulphur on yield and quality of potato (Solanium tubersoum L.). International Journal of Agricultural Research. 6:2, pp:143-148.

Shiferaw, H. 2014. Digital soil mapping: Soil fertility status and fertilizer recommendation for Ethiopian agricultural land (Conference paper). Addis Ababa, Ethiopia.

Singh, J.P. and Shrivastava, O.P. 1995. Role and requirement of sulphur in growth and tuber yield of potato (Solanum tuberosumL). Indian Journal of Agricultural Sciences. 65(4): 288- 289.

Sommerfeldt, G., T. and Knutson K. W., 1965. Effects of nitrogen and phosphorus on the growth and development of russet burbank potatoes grown in southeastern Idaho. American Journal of Potato Research 42:12: Pp: 351360.

Sriom, D.P. Mishra, Priyanka Rajbhar, Devraj Singh, Rajat Kumar Singh and Sudhir Kumar Mishra. 2017. Effect of different levels of nitrogen on growth and yield in potato (Solanum tuberosum L.) CV. Kufri Khyati. Int. J. Curr. Microbiol. App. Sci. 6(6): 1456-1460. doi: https://doi.org/10.20546/ijcmas.2017.606.170.

Sud, K.C. and R.C. Sharma, 2002. Sulphur Needs of Potato under Rainfed Conditions in Shimla Hills. In: Potato Global Research and Development, Paul Khurana, S.M., G.S. Shekhawat, S.K. Pandey and B.S. Singh (Eds.). Vol. 2. Indian Potato Association, Shimla, pp: 889-899.

Tekalign, T., and P.S. Hammes. 2005. Growth and productivity of potato as influenced by cultivar and reproductive growth I, stomatal conductance, rate of transpiration, net photosynthesis and dry matter production and allocation. Scientia Horticulture Journal 105:13-27.

Tewodros A. 2014. Analysis of Seed Potato (Solanum tuberosum L.) Systems with Special Focus in Ethiopia: Review. Asian Journal of Agricultural Research, 8: 122-135.

Thompson, H.C. and W.C. Kelly, 1972. Vegetable Crops. Tata McGraw Hill Publ. Co. Ltd., New Delhi, pp: $372-$ 385.

Van-Reeuwijk, L., 1992. Procedures for Soil Analysis (3rd ed.), International Soil Reference and Information Center (ISRIC), Wageningen, The Netherlands. 
Walkley, A. and I. A. Black. 1934. An examination of Degtjareff method for determining soil organic matter and a proposed modification of the chromic acid titration method. Soil Sci. 37: 29-37.

White, R.P. and Sanderson J.B. 1983. Effect of planting date, nitrogen rate, and plant spacing on potatoes grown for processing in Prince Edward Island. American Potato Journal, 60:2, pp: 115-26.

Wilcox, G. E., and J. Hoff. 1970. Nitrogen fertilization of potatoes for early summer harvest. Am. Potato J. 47:99102.

Yayeh, S. G., Alemayehu, M., Hailesilassie, A., and Yigzaw, D. 2017. Economic and agronomic optimum rates of NPS fertilizer for irrigated garlic (Allium sativum L.) production in the highlands of Ethiopia. Cogent Food \& Agriculture. 3:1333666.

Yohanes U., 1994. The effect of nitrogen, phosphorus, potassium and sulfur on the yield and yield components of Ensete (Ensete ventricosum W.) in Southwest of Ethiopia, PhD Thesis, Gieben, Germany.

Table 1: Soil physical and chemical properties of the experimental site before planting

\begin{tabular}{|c|c|c|}
\hline Soil texture & Content & Rating \\
\hline Sand $(\%)$ & 72 & \\
\hline Silt (\%) & 16 & \\
\hline Clay $(\%)$ & 12 & \\
\hline Textural Class & Sandy loam & Sandy loam \\
\hline \multicolumn{3}{|l|}{ Chemical properties } \\
\hline $\mathrm{pH}$ & 6.8 & Slightly acidic \\
\hline Electrical Conductivity $(\mathrm{ds} / \mathrm{m})$ & 4.45 & Slightly saline \\
\hline Organic Sulfur $(\%)$ & 0.0114 & Very Low \\
\hline Organic carbon $(\%)$ & 1.326 & High \\
\hline Organic Matter $(\%)$ & 2.286 & Very High \\
\hline Total Nitrogen $(\%)$ & 0.1143 & Low \\
\hline Available Phosphorus (ppm) & 11.18 & Extremely low \\
\hline \multirow{2}{*}{$\begin{array}{l}\text { Exchangeable Cations } \\
(\mathrm{meq} / 100 \mathrm{~g})\end{array}$} & 0.391 & \\
\hline & 1.242 & High \\
\hline
\end{tabular}

Table 2:-The effect of variety and NPS fertilizer rates on plant height, stem number per hill and flowering days of potato at Abaso Kotu, Dessie Zuria district, Northeast Ethiopia.

\begin{tabular}{llll}
\hline Variety & Plant height $(\mathrm{cm})$ & Number of stem hill $^{-1}$ & Days to flowering \\
\hline Local & 71.47 & 6.78 & $55.17^{\mathrm{b}}$ \\
Belete & 75.52 & 6.22 & $59.17^{\mathrm{a}}$ \\
\hline LSD & $\mathrm{Ns}$ & $\mathrm{Ns}$ & 1.741 \\
\hline NPS fertilizer rate $\left(\mathrm{N}: \mathrm{P}_{2} \mathrm{O}_{5}: \mathrm{S}\right)$ & & & \\
\hline \multicolumn{1}{c}{$0: 0: 0$} & $62.27^{\mathrm{c}}$ & 5.17 & 56.50 \\
$111: 89.7: 0$ & $69.40^{\mathrm{bc}}$ & 5.67 & 58.33 \\
$111: 89.7: 16.52$ & $87.60^{\mathrm{a}}$ & 7.17 & 55.17 \\
$55.5: 89.7: 16.52$ & $76.73^{\mathrm{b}}$ & 7.17 & 56.17 \\
$111: 44.85: 8.26$ & $70.10^{\mathrm{bc}}$ & 7.00 & 58.83 \\
$55.5: 44.85: 8.26$ & $74.87^{\mathrm{b}}$ & 6.83 & 58.00 \\
\hline LSD & 12.78 & $\mathrm{Ns}$ & $\mathrm{ns}$ \\
CV & 10.27 & 23.92 & 4.4 \\
\hline
\end{tabular}

Means in columns with the same letter are not significantly different from each other at $\mathrm{P} \leq 0.05$. 
Table 3: Interaction effect of variety and NPS fertilizer rates on days to maturity of potato at Abaso Kotu, Dessie Zuria district, Northeast Ethiopia.

\begin{tabular}{|c|c|c|}
\hline \multirow{3}{*}{ Fertilizer Rate $\left(\mathrm{N}: \mathrm{P}_{2} \mathrm{O}_{5}: \mathrm{S}\right)$} & \multicolumn{2}{|l|}{ Variety } \\
\hline & Local & Belete \\
\hline & \multicolumn{2}{|l|}{ Days to Maturity } \\
\hline $0: 0: 0$ & $113.33^{\mathrm{de}}$ & $111.00^{\mathrm{e}}$ \\
\hline $111: 89.7: 0$ & $114.67^{d}$ & $114.00^{\mathrm{de}}$ \\
\hline $111: 89.7: 16.52$ & $119.33^{\mathrm{bc}}$ & $124.33^{\mathrm{a}}$ \\
\hline $55.5: 89.7: 16.52$ & $116.33^{\mathrm{cd}}$ & $120.00^{\mathrm{b}}$ \\
\hline $111: 44.85: 8.26$ & $114.00^{\mathrm{de}}$ & $120.00^{\mathrm{b}}$ \\
\hline $55.5: 44.85: 8.26$ & $114.33^{\mathrm{de}}$ & $118.67^{\mathrm{bc}}$ \\
\hline LSD & 3.428 & \\
\hline $\mathrm{CV} \%$ & 1.74 & \\
\hline
\end{tabular}

Means with the same letter are not significantly different from each other at $\mathrm{P} \leq 0.05$.

Table 4. The effect of variety and NPS fertilizer rates on above ground biomass, below ground biomass, total biomass and tuber number of potato plant at Abaso Kotu, Dessie Zuria district, Northeast Ethiopia.

\begin{tabular}{|c|c|c|c|c|}
\hline Variety & $\begin{array}{l}\text { Above ground } \\
\text { biomass }\left(\mathrm{g} \text { hill }^{-1}\right)\end{array}$ & $\begin{array}{l}\text { Below ground biomass } \\
\left(\mathrm{g} \mathrm{hill}^{-1}\right)\end{array}$ & $\begin{array}{l}\text { Total biomass (g } \\
\text { hill }^{-1} \text { ) }\end{array}$ & $\begin{array}{l}\text { Tuber number } \\
\text { hill }^{-1}\end{array}$ \\
\hline Local & $59.6^{\mathrm{b}}$ & $224.9^{\mathrm{b}}$ & $284.5^{\mathrm{b}}$ & 14.11 \\
\hline Belete & $91.8^{\mathrm{a}}$ & $261.2^{\mathrm{a}}$ & $352.9^{\mathrm{a}}$ & 14.11 \\
\hline LSD & 8.71 & 27.16 & 31.69 & Ns \\
\hline \multicolumn{5}{|c|}{$\begin{array}{l}\text { NPS fertilizer rate } \\
\left(\mathrm{N}: \mathrm{P}_{2} \mathrm{O}_{5}: \mathrm{S}\right)\end{array}$} \\
\hline $0: 0: 0$ & $45.60^{\mathrm{d}}$ & $171.1^{\mathrm{c}}$ & $216.7^{d}$ & $10.00^{\mathrm{b}}$ \\
\hline 111: $89.7: 0$ & $73.47^{\mathrm{bc}}$ & $244.7^{\mathrm{ab}}$ & $318.1^{\mathrm{bc}}$ & $13.67^{\mathrm{a}}$ \\
\hline $111: 89.7: 16.52$ & $103.24^{\mathrm{a}}$ & $264.9^{\mathrm{ab}}$ & $368.1^{\mathrm{ab}}$ & $15.00^{\mathrm{a}}$ \\
\hline $55.5: 89.7: 16.52$ & $87.83^{b}$ & $290.9^{a}$ & $378.8^{\mathrm{a}}$ & $15.67^{\mathrm{a}}$ \\
\hline 111: 44.85:8.26 & $73.2^{\mathrm{bc}}$ & $235.3^{b}$ & $308.5^{c}$ & $15.17^{\mathrm{a}}$ \\
\hline $55.5: 44.85: 8.26$ & $70.75^{\mathrm{c}}$ & $251.2^{\mathrm{ab}}$ & $322.0^{\mathrm{bc}}$ & $15.17^{\mathrm{a}}$ \\
\hline LSD & 15.08 & 47.05 & 54.88 & 3.140 \\
\hline $\mathrm{CV}$ & 16.6 & 16.2 & 14.4 & 18.6 \\
\hline
\end{tabular}

Means in columns with the same letter are not significantly different from each other at $\mathrm{P} \leq 0.05$.

Table 5: The effect of variety and NPS fertilizer rates on average tuber weight, marketable yield, unmarketable yield and total tuber yield of potato at Abaso Kotu, Dessie Zuria district, Northeast Ethiopia.

\begin{tabular}{|c|c|c|c|c|}
\hline Variety & $\begin{array}{l}\text { Average tuber weight } \\
\left(\mathrm{kg} \mathrm{hill}{ }^{-1}\right)\end{array}$ & $\begin{array}{l}\text { Marketable yield ( } \mathrm{t} \\
\mathrm{ha}^{-1} \text { ) }\end{array}$ & $\begin{array}{l}\text { Unmarketable yield }(\mathrm{t} \\
\left.\mathrm{ha}^{-1}\right)\end{array}$ & $\begin{array}{l}\text { Total Tuber }(\mathrm{t} \\
\left.\mathrm{ha}^{-1}\right)\end{array}$ \\
\hline Local & $1.399^{\mathrm{b}}$ & $41.46^{\mathrm{b}}$ & $0.419^{\mathrm{b}}$ & $41.9^{\mathrm{b}}$ \\
\hline Belete & $1.606^{\mathrm{a}}$ & $48.11^{\mathrm{a}}$ & $0.501^{\mathrm{a}}$ & $48.6^{\mathrm{a}}$ \\
\hline LSD & 0.163 & 5.02 & 0.052 & 5.07 \\
\hline \multicolumn{5}{|c|}{$\begin{array}{l}\text { NPS fertilizer rate } \\
\left(\mathrm{N}: \mathrm{P}_{2} \mathrm{O}_{5}: \mathrm{S}\right)\end{array}$} \\
\hline $0: 0: 0$ & $1.123^{\mathrm{d}}$ & $31.50^{c}$ & $0.358^{\mathrm{c}}$ & $31.85^{\mathrm{c}}$ \\
\hline $111: 89.7: 0$ & $1.330^{\mathrm{cd}}$ & $45.19^{\mathrm{ab}}$ & $0.455^{\mathrm{ab}}$ & $45.65^{\mathrm{ab}}$ \\
\hline $111: 89.7: 16.52$ & $1.460^{\mathrm{bc}}$ & $48.78^{\mathrm{ab}}$ & $0.491^{\mathrm{ab}}$ & $49.27^{\mathrm{ab}}$ \\
\hline $55.5: 89.7: 16.52$ & $1.817^{\mathrm{a}}$ & $53.61^{\mathrm{a}}$ & $0.542^{\mathrm{a}}$ & $54.15^{\mathrm{a}}$ \\
\hline $111: 44.85: 8.26$ & $1.573^{\mathrm{abc}}$ & $43.36^{\mathrm{b}}$ & $0.44 b^{c}$ & $43.80^{\mathrm{b}}$ \\
\hline $55.5: 44.85: 8.26$ & $1.710^{\mathrm{ab}}$ & $46.26^{\mathrm{ab}}$ & $0.475^{\mathrm{ab}}$ & $46.73^{\mathrm{ab}}$ \\
\hline LSD & 0.283 & 8.69 & 0.090 & 8.78 \\
\hline $\mathrm{CV}$ & 15.7 & 16.2 & 16.4 & 16.2 \\
\hline
\end{tabular}

Means in columns with the same letter are not significantly different from each other at $\mathrm{P} \leq 0.05$. 